\title{
THE RELATIONSHIP AMONG USER, ACTIVITY AND SPACE OF STREET FURNITURE PLACED AT KANUNI CAMPUS - KARADENIZ TECHNICAL UNIVERSITY
}

\author{
B. C. Kurdoğlu ${ }^{\text {a }}$, K. T. Çelik ${ }^{\text {b }, ~ S . ~ S . ~ K u r t ~ K o n a k o g ̆ l u ~}{ }^{\text {c, } *, \text { Y. S. Erbaş }}{ }^{\mathrm{d}}$ \\ ${ }^{a}$ KTU, Forestry Faculty, 61080 Trabzon, Turkey - banukurdoglu@gmail.com \\ ${ }^{\mathrm{b}}$ Landscape Architect (MSc), 61080 Trabzon, Turkey - kadirtolgacelik@gmail.com \\ ${ }^{\mathrm{c}}$ KTU, Forestry Faculty, 61080 Trabzon, Turkey - sultansevinckurt@gmail.com \\ d KTU, Engineering Faculty, 61080 Trabzon, Turkey - yselcukerbas@ gmail.com
}

KEY WORDS: GIS, YEDBIS, Harmony

\begin{abstract}
:
The purpose of this study, 2369 street furniture at the campus mentioned to the thesis study named "Generating a GIS-Based Campus Street Furniture Information System (YEDBIS): Example of Kanuni Campus - Karadeniz Technical University" are to question the harmony statuses of space form, actual activity in space, space size, natural materials used space, usage density of space, surface materials of space, users, and the other of them. The harmony statuses of the street furniture were fixed by observation works and field determinations at the campus. Findings obtained observations were recorded to identification cards by writing " 0 " value for disharmony, "1" value for partly harmony and "2" value for harmony. Then, the data were analyzed in YEDBIS, which is based on GIS. Then, the data were analyzed in YEDBIS, which is based on GIS, by using ArcMap 10.0 programme. However, due to the absence of web support generated for the YEDBIS, with current data querying and analysis of this data was carried out only in a computer where YEDBIS is located.

The results of the analysis indicates that 2369 street furniture were found to be disharmony with space form, with surface materials of space, with natural materials used space and with other street furniture in space, and to be partly harmony actual activity in space, space size, usage density of space and users. Also, the regions and nearby around of the buildings at the campus where were disharmony, partly harmony and harmony of the street furniture were established by using YEDBIS.
\end{abstract}

\section{INTRODUCTION}

Human beings are in need of artificial environment, as well as the natural environment, in the areas they live in. Street furniture, which is actually made up of artificial materials, play an equally important role in composition of the man-made environment beside plants, the natural elements of the environment (Kurdoğlu et. al., 2013).

A space is supposed to meet the physical, physiological and psychological needs of its users in order to be preferable and perdurable for the users (Aksu et. al., 2011). Elements of street furniture make the urban spaces they are placed in more habitable and perceivable, and establish a visual and physical bond between the user and the city. They generate a common language by integrating with their surroundings (Bayraktar et. al., 2008). Apart from its implementation in planning and organization of urban living spaces, street furniture is also exploited in gaining an identity for the city (Kurt \& Cindık, 2013). In order to meet social, cultural and recreational needs of users and to satisfy their needs in an healthier way, on the other hand, street furniture should be in harmony with the spaces where it is placed, activities held in these spaces and the users of such spaces (Çelik, 2015).

Utilization style and intensity of urban spaces and the street furniture contained within these spaces depict the socioeconomic and cultural status, habits, tastes and aesthetic levels of their users (Yurdugüzel, 2013). The criteria that can cause changes in design and affect the taste of the potential user are; being compatible with color, material and the environment, having measure-rate balance and functional suitability, and being different, impressive, interesting, flamboyant, original, meaningful and symbolic (Aksu, 2012). Besides, they must be designed taking into account the ergonomic features that will not limit the user nor hinder the users' privacy (Bekçi and Taşkan, 2012). Functional and aesthetic characteristics (lines, dimension, form, color, texture etc.) of the street furniture and anthropometric measurement criteria must also be considered in the design process, and they should also be perceivable (Ghorab and Yücel Caymaz, 2015).

University campuses, where educational and scientific studies are conducted, also make use of street furniture to enhance the quality of life of their students and personnel, and to meet their social, cultural and recreational needs (Çelik, 2015).

Harmony of the elements of street furniture placed within Karadeniz Technical University (KTU) - Kanuni Campus with the form of the space, activities held in the given space, size of the space, natural materials used in the space, intensity of utilization of the space, artificial materials used in the space, users of the space and other elements of street furniture are investigated in the current study. Geographical Information System (GIS), which is a computer-based system that presents the necessary actual and detailed data in a rapid and secure way along with spatial and statistical analyses and enables easy access to required source of information, was exploited for the sake of investigation. Data concerning the street furniture in the area of study were recorded by generating ArcMap 10.0 GIS

\footnotetext{
* Corresponding author
} 
based Campus Street Furniture Information System (YEDBIS) Due to the absence of web support generated for the YEDBIS, with current data querying and analysis of this data was carried out only in a computer where YEDBIS is located. YEDBIS is not integrated with other GIS based work in this state.

\section{METHODS}

\subsection{Study Area}

The area of study constitutes an area of $89.875 \mathrm{~m} 2$ on Karadeniz Technical University Kanuni Campus located in Trabzon (Figure 1). Rector's Office and its surroundings, all Institutes and their surroundings, all faculties and their surroundings, Higher School of Foreign Languages, surroundings of Research Centers, sports venues, nearby areas of Atatürk Cultural Center, Prof. Dr. Osman Turan Cultural and Convention Center and all other social facilities were included within the scope of the study. However, some areas in the campus could be incorporated into the operating limits. Faculty of Medicine and its surroundings, continues the independent nature of the work and the campus landscape was formed due to participate in the study. Due to construction if the new Higher School of Foreign Languages building and its surroundings create the risk of accidents at work it is likely to take part in the study. It is currently under construction, and because of security concerns, the residence of the Rector and its surroundings were left out of the research study. The elements of street furniture (lighting elements, signboards and information boards, sitting elements, artistic objects, water elements, roofing elements, rubbish bins, advertising signboards and billboards, public transportation stops and flower beds) placed in and around all the buildings and social spaces comprised the main material of the current study.

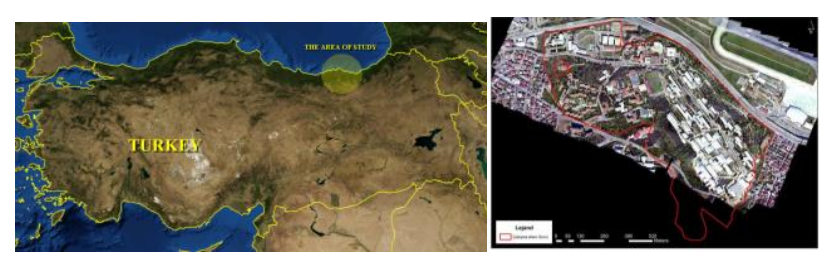

Figure 1. The borders of the study area.

\subsection{Method}

The positional data of 400 pieces of street furniture, walls, roads, stairs and campus buildings acquired from the base of the Scientific Research Project: "A Research on Generating 'The Information System Model of Natural and Artificial Landscape Materials of Universities' in Karadeniz Technical University Campus Example" (BAP-2, 1171 No) conducted by Kurdoğlu et al. (2012) and Kurdoglu et al. (2015) in GIS environment were used in the current study. First of all, positional and nonpositional data of 2369 pieces of street furniture on the above mentioned base and their harmony status attained through onsite observation were recorded on separate identity cards (Figure 2).

\begin{tabular}{|c|c|c|c|}
\hline \multicolumn{4}{|c|}{$\begin{array}{l}\text { STREET FURNITE IDENTIFICATION CARD ON KTU } \\
\text { KANUNI CAMPUS }\end{array}$} \\
\hline Photo: & \multicolumn{2}{|c|}{ Observation Place: } & No: \\
\hline & \multirow{2}{*}{$\begin{array}{l}\text { Kinds of } \\
\text { Street } \\
\text { Furniture }\end{array}$} & Lighting Element & Canopy Structure \\
\hline & & $\begin{array}{l}\text { Signboards and } \\
\text { Information Board }\end{array}$ & $\begin{array}{l}\text { Advertising } \\
\text { Boards }\end{array}$ \\
\hline
\end{tabular}

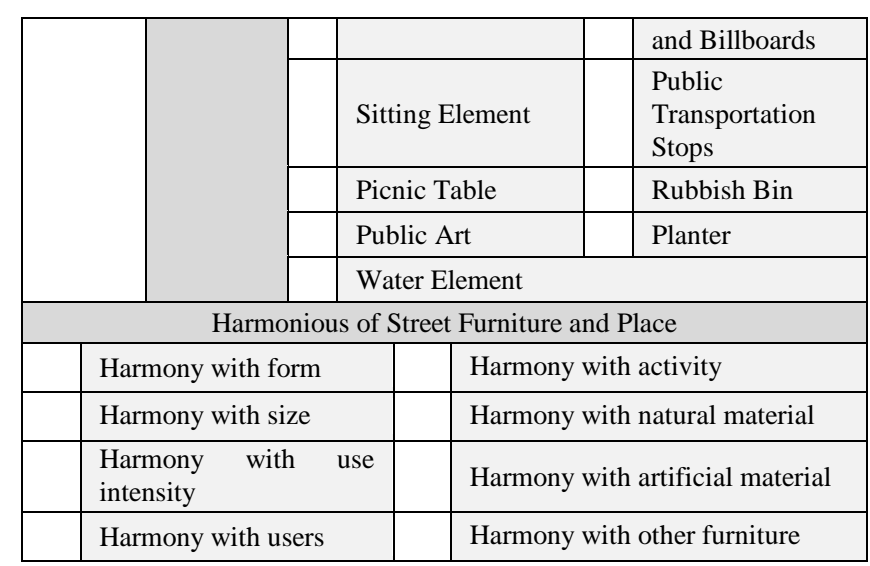

Figure 2. Street Furniture Identification Card on KTU Kanuni Campus.

The criteria that street furniture is supposed to meet in terms of dimension, color, material, function and position were determined in accordance with the standards put forward by Halprin (1963), Husain (1972), Uzun (1997), Yaylalı (1998), Kaya (2001), Uzun (2002), Öner Bilen (2004), Yörük et al., (2006), Yücel (2006), Bulut et al., (2008), Güremen (2011), Önder et al., (2012) and Hastürk (2013).

While recording the harmony status of the elements of street furniture on respective identity cards, they were scored based on the following criteria:

- Form and harmony; the stylistic (square, rectangular, triangle, circle, ellipse, polygon) harmony between the element of street furniture and space upon inspection of street furniture and the space they are placed in,

- $\quad$ Activity and harmony; implementation of the element of street furniture in proportion with the space it is placed in (big furniture-small space, big space inadequate furniture etc.) and harmony in terms of capacity of meeting the needs.

- Harmony with natural material; harmony between the element of street furniture and the natural materials (trees, bushes, ground covers, natural stones etc.) located in the space where it is placed in terms of limiting-hindering one another,

- Harmony with intensity of utilization; harmony in terms of the capacity of the element of street furniture to meet the intensity of utilization in the respective space,

- Harmony with artificial material; harmony between the element of street furniture and the structures (stairs, walls, buildings etc.) located around them,

- Harmony with user; harmony of the element of street furniture in respect to ergonomic and anthropometric standards of its users,

- $\quad$ Harmony with other pieces of street furniture; harmony of the given street furniture with other pieces of street furniture in terms of dimensions, color, material, function and position.

During the observation process, the harmony scores of the elements of street furniture were recorded on their respective ID cards as 0 if one element is inharmonious, 1 if is partially harmonious, and 2 in the case of full harmony. The data processing of the ID card, which is then entered into YEDBIS based GIS using ArcMap 10.0 programme. However, due to the absence of web support generated for the YEDBIS, with current data querying and analysis ("Frequency", "Intersect" and 
"Buffer") of this data was carried out only in a computer where YEDBIS is located.

\subsection{Findings}

In this section, the findings obtained from all of the abovementioned urban equipment compability were analyzed on YEDBIS in accordance with the standards identified by Kurdoğlu et al. (2012) (Table 1).

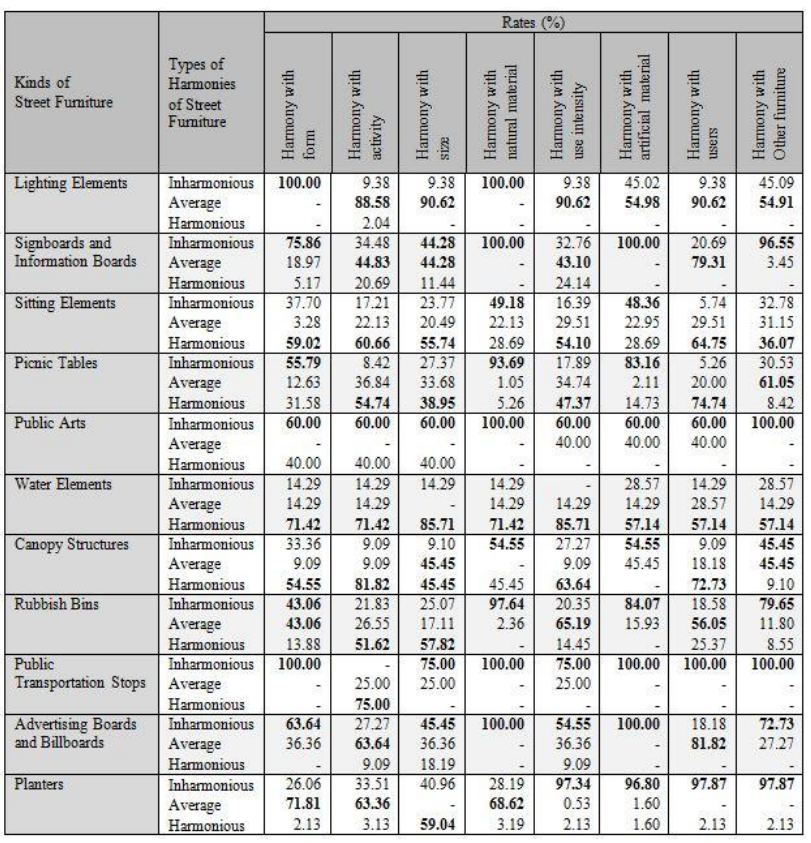

Table 1. The Percentages of the YEDBIS Analysis Results of the Respective Elements of Street Furniture.

According to the data acquired from YEDBIS, it was found out that the sitting elements, picnic tables, water elements and roofing elements are harmonious; lighting elements are partially harmonious, and signboards and information boards, artistic objects, rubbish bins, public transportation stops, advertising signboards and billboards, and flower beds are mostly inharmonious.

Intersect and buffer analyses run on YEDBIS data revealed that the $22.73 \%$ of lighting elements that are inharmonious with the activity are placed around the boys' dormitory, $13.64 \%$ were around YURT-KUR Directorate; $33.33 \%$ of the inharmonious signboards are located near the Faculty of Economic and Administrative Sciences; $23.33 \%$ of the inharmonious rubbish bins are placed around the Faculty of Law and $21.43 \%$ of them are around the Department of Health, Culture and Sports.

$22.22 \%$ of lighting elements that are inharmonious with the user are placed around the boys' dormitory, $13.33 \%$ are around YURT-KUR Directorate; $28.57 \%$ of inharmonious rubbish bins are around the Higher School of Foreign Languages and $21.43 \%$ of them are located near the Faculty of Economic and Administrative Sciences.

It was observed that $25.00 \%$ of lighting elements that are inharmonious with the natural materials used in the same space are located around the boys' dormitory, $15.00 \%$ are around YURT-KUR Directorate, $10 \%$ are around the Higher School of Foreign Languages, $10 \%$ are around the Department of Health, Culture and Sports, and $10 \%$ are in close proximity to the Faculty of Topographical Engineering. $31.58 \%$ of the inharmonious flowerbeds, on the other hand, are located around Faik Ahmet Barutçu Library, 13.16\% are around the Higher School of Foreign Languages, $13.16 \%$ are around the building of Student Affairs and $13.16 \%$ are around the Department of Health, Culture and Sports.

Mapping of each element of street furniture in terms of all the harmony criteria is also possible through YEDBIS. As an example of the maps created in this way, the map showing the fully harmonious, partially harmonious and inharmonious rubbish bins and containers with their users is presented in Figure 3. It was found out that most of the rubbish bins and containers in the campus area are partially harmonious with users.

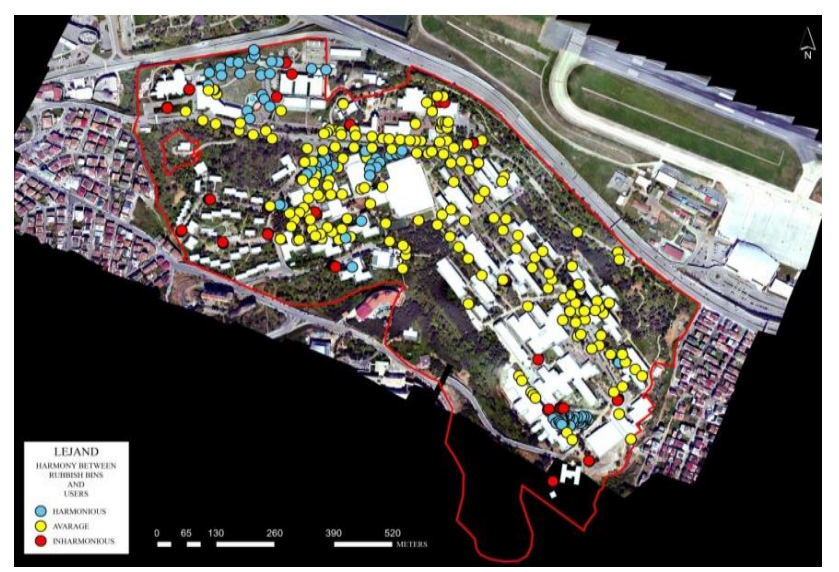

Figure 3. Harmony between Rubbish Bins and Users.

\subsection{Discussion}

Form, which is defined as the structure of a whole, prescribes function, dimensions and material. Form should be determined suitable for the function and service attributed to street furniture, and they should be designed for the purpose of any element of street furniture (Arcan and Evci, 1992). In their study relating the street furniture in Antalya, Olgun and Yilmaz (2013) pointed out the existence of street furniture that was designed without taking into account anthropometric measurements, as well as inharmonious designs. In the study conducted on KTU Kanuni Campus, it was also revealed that most of street furniture -except for sitting elements, water elements and roofing elements, are inharmonious.

Material is one of the components that affect design of the street furniture. Material used in the making of street furniture helps portray the functionality of the piece in the most appropriate way (Aksu, 2012). Materials that stimulate human beings psychologically induce the feeling of peace and comfort, creativity and imagination, impetus and safety. Artificial materials, on the other hand, contribute to the modern perception of the space (Dascula, 2011). Bulut et al. (2008) found out in the study they conducted in the city center of Erzurum that ergonomic concerns were not taken into account in preference of materials while implementing street furniture. In the study they did in Uzun Sokak area in Trabzon, Bayramoğlu and Özdemir (2012) revealed that street furniture did not constitute a harmonious whole with the environment they are surrounded by, and resolved that harmony with the natural environment had not been considered in the first place. In the current study, it was detected that only water elements are harmonious with natural and artificial materials, but rest of the street furniture used in the campus area is inharmonious. 
In their study on the street furniture located in open green spaces in Bartın, Bekçi and Taşkan (2012) concluded that users perceived other street furniture inharmonious to one another. In the study conducted on the street furniture in Ankara by Sakal (2007), it was stressed that the harmony between the elements of street furniture was lost due to the fact that different landscape plans were implemented over time. In the current study conducted on KTU Kanuni Campus, it was concluded that items of street furniture are mostly partially-harmonious with other street furniture.

Gülemen (2011) found in the study he conducted in Ziya Paşa Avenue and Atatürk Avenue in Amasya that the street furniture placed in these sites could not bear the load of intensive usage of the spaces, that they hindered users and they were not harmonious with the intensity of usage. In the current study, too, it was found out that the street furniture used here is not harmonious with the intensity of usage, but it is mostly harmonious with the users.

\section{CONCLUSION}

According to the inquiries and analyses conducted on YEDBIS, it was observed that - of 2369 items of street furniture located within the campus area- $76.66 \%$ is inharmonious with the form of the space, $89.78 \%$ is inharmonious with the artificial materials used in the space and $76.66 \%$ is not harmonious with the natural materials of the space. It was detected that $65.75 \%$ of it is partially-harmonious with the activities held in the space, while other partial-harmony figures are $60.35 \%$ for the size of the space, $67.40 \%$ for the intensity of usage, $66.17 \%$ for the users of the space, and $56.97 \%$ for other elements of street furniture located in the same space. In the light of the analyses made, findings on whether the street furniture located within Karadeniz Technical University Kanuni Campus area are harmonious with the form of the space, materials used, natural materials and other items of street furniture placed in the same place were further illustrated. As it was done in the current study, other evaluations for problems and possible solutions that are deemed necessary in terms planning could be illustrated directly on YEDBIS. Most data that may be needed during landscape planning and design processes for campus areas could easily be stored, analyzed and subsequently presented thanks to YEDBIS.

Master plans that include street furniture should be prepared for campuses, and the items of street furniture should be placed within the campus area in accordance with a planning and design process. Mass produced standard street furniture should not be randomly fitted around the spaces. Depending on the intended user of a given space and the activities they will enable, street furniture should comply with the standards in terms of such features as form, dimensions, material, vegetation and other street furniture.

\section{ACKNOWLEDGEMENTS}

In the current study, the author expresses his special thanks to the study group of the Scientific Research Project: "A Research on Generating 'The Information System Model of Natural and Artificial Landscape Materials of Universities' in Karadeniz Technical University Campus Example" (BAP-2, 1171 No), and the writer of the master's thesis "Generating a GIS based Campus Street Furniture Information System (YEDBIS): Example of Karadeniz Technical University Kanuni Campus, who allowed the author to benefit from their works.

\section{REFERENCES}

Aksu, Ö. V., 2012. Kent Mobilyaları Tasarımında Özgün Yaklaşımlar, Inonu University Journal of Art and Design, Annual Special Issue, 2(6), pp. 373-386.

Aksu, Ö. V., Demirel, Ö. and Bektaş, N., 2011. Trabzon Kenti İlköğretim Okul Bahçelerinde Donatı Elemanları Üzerine Bir Araştırma, İn̈nü University Journal of Art and Design, 1(3), pp. 243-254.

Arcan, E. F. and Evci, F., 1992. Mimari Tasarıma Yaklaşım, Iki K Publisher, Istanbul, Turkey.

Bayraktar, N., Tekel, A. and Yalçıner Ercoşkun, Ö., 2008. Ankara Atatürk Bulvarı Üzerinde Yer Alan Kentsel Donatı Elemanlarının Sinıflandırılması, Değerlendirilmesi ve Kent Kimliği İlişkisi. Gazi University Journal of Engineering and Architecture, 23(1), pp. 105-118.

Bayramoğlu, E. and Özdemir, B., 2012. Trabzon Kent Merkezi, Uzun Sokak Kentsel Donatı Elemanlarının Kent Kimliği Açısından Değerlendirilmesi. Kastamonu University Journal of Forestry Faculty, 12(2), pp. 182-191.

Bekçi, B. and Taşkan, G., 2012. Açık Yeşil Alanlardaki Kent Donatılarının Kişisel Mekan Uzaklığına Etkisi: Bartın Kenti Örneği. Bartın University Journal of Forest Faculty, 14(22), pp. 61-71.

Bulut, Y., Atabeyoğlu, Ö. and Yeşil, P., 2008. Erzurum Kent Merkezi Donat1 Elemanlarının Ergonomik Özelliklerinin Değerlendirilmesi Üzerine Bir Araştırma, Ankara University Journal of Agricultural Sciences, 14(2), pp. 131-138.

Çelik, K. T., 2015. CBS Tabanlı Bir Yerleşke Donatı Bilgi Sisteminin (YEDBIS) Oluşturulması: Karadeniz Teknik Üniversitesi Kanuni Yerleşkesi Örneği, Master's Thesis, Karadeniz Technical University, Institute of Science, Department of Landscape Architecture, Trabzon, Turkey.

Dascalu, D. M., 2011. Landscape Effects of Urban Furniture Tectures, Bulletin UASVM Horticulture, 68(1), pp. 324-331.

Ghorab, B. and Yucel Caymaz, G. F., 2015. Evaluation of Street Furniture According to Basic Design Principles, International Journal of Electronics, Mechanical and Mechatronics Engineering, 4(3), pp. 757-772.

Güremen, L., 2011. Kent Kimliği ve Estetiği Yönüyle Kentsel Donatı Elemanlarının Amasya Kenti Özelinde Araştırılması, eJournal of New World Sciences Academy Social Science, 6(2), pp. 254-291.

Halprin, L., 1963. Cities, New York: Reinhold Publishing Corp., pp 85-102.

Hastürk, E. Y., 2013. Statik Antropometrik Verilerle Ergonomik Oturma Mobilyası Tasarım1, Doctoral Thesis, Ankara University, Institute of Social Science, Department of Anthropology (Physics Anthropology), Ankara, Turkey.

Husain, M., 1972. An Urban Environments System, Master Thesis, ODTU, Institute of Science, Ankara, Turkey.

Kaya, E., 2001. A Study on Street Furniture Design Criteria for Bus Stops, a Dissertation Submitted to the Graduate School in Partial Fulfillment of the Requirements for the Degree of Master of Industrial Design, Izmir Institute of Technology. Izmir, Turkey. 
Kurdoglu, B. Ç., Demirel, Ö., Nişanc1, R., Özdemir, B., Bayramoğlu, E. and Erbaş, Y. S., 2012. A Research on Generating 'The Information System Model of Natural and Artificial Landscape Materials of Universities' in Karadeniz Technical University Campus Example. Scientific Research Project Final Report. No: 1171, Trabzon, Turkey.

Kurdoglu, B. Ç., Erbaş, Y. S., Demirel, Ö., Nişancı, R. and Çelik, K. T., 2015. An Investigation on Creating University Landscape Materials Information System Model: Karadeniz Technical University Case Study, In: Environment and Ecology at the Beginning of 21. Century, Sofia, Bulgaria, Chapter 32, pp.456-471.

Kurdoğlu, B. Ç., Özdemir Işık, B. and Bayramoğlu, E., 2013. Doğal-Yapay Peyzaj Materyalleri ve Kullanıcı İlişkisi: KTÜ Kanuni Yerleşkesi Örneği, Kastamonu University Journal of Forestry Faculty, 13(1), pp. 164-174.

Kurt, S. S. and Cindık, Y., 2013. A Study on Street Furniture of Trabzon City, International Caucasian Forestry Symposium, Artvin, Turkey, pp. 712-718.

Önder, S., Polat, A. T. and Öztürk, A., 2012. The Evaluation of Ergonomic Situations of the Equipment Elements in Selcuk University Campus, Konya, Turkey. Journal of Selçuk University Natural and Applied Science, 1(1), pp. 30-52.

Öner Bilen, S., 2004. Kentsel Dış Mekânların Tasarımında Antropometrik Verilere Bağlı Olarak Peyzaj Elemanlarının Ankara Örneğinde Araştırılması, Doctoral Thesis, Ankara University, Institute of Science, Ankara, Turkey.

Sakal, A. N., 2007. Ankara'da Kentsel Donatıların Peyzaj Planlama ve Tasarımı Açısından Analizi ve Değerlendirilmesi, Doctoral Thesis, Ankara University, Institute of Science, Department of Landscape Architecture, Ankara, Turkey.

Uzun, G., 1997. Peyzaj Konstrüksiyonu, Çukurova University, Faculty of Agricultural, Adana.

Uzun, G., 2002. Peyzaj Konstrüksiyonu II, Çukurova University, Faculty of Agricultural, Adana, 137:A-42, 296.

Yaylalı, S., 1998. Kent Mobilyaları Tasarımında Kullanılabilecek Kavramsal Bir Model, Master Thesis, İstanbul Technical University, Institute of Science, İstanbul, Turkey.

Yörük, İ., Gülgün, B., Sayman, M. and Ankaya, F. Ü., 2006. Peyzaj Planlama Çalışmaları Kapsamında Ege Üniversitesi Kampüs Örneğindeki Peyzaj Donatı Elemanlarının ErgonomikAntropometrik Aç1dan İrdelenmesi, Ege University Journal of Agricultural Faculty, 43(1), pp. 157-168.

Yücel, G. F., 2006. Kamusal Açık Mekânlarda Donatı Elemanlarının Kullanımı, Journal of Ege Mimarlı, 4(22), pp. 26-29.

Yurdugüzel, O. T., 2013. Yozgat Toki Konutlarının Kullanışlı1ık ve Kullanıcı Memnuniyeti Kapsamında Değerlendirilmesi, 19. National Ergonomic Congress, Balıkesir, Turkey, pp.707-714. 